Assiut University web-site: www.aun.edu.eg

\title{
PROTECTIVE EFFECT OF THYMUS VULGARIS EXTRACT AGAINST CADMIUM INDUCED NEPHROTOXICITY AND TESTICULAR DAMAGE IN ALBINO RATS
}

\author{
SAMAH ABOU ASA ${ }^{1}$; EL-SHAYMAA EL-NAHASS ${ }^{2}$ and DOAA ABDELHADY ${ }^{3}$ \\ ${ }^{1}$ Department of Pathology, Faculty of Veterinary Medicine, Kafr Elsheikh University, Kafr Elsheikh, Egypt. \\ ${ }^{2}$ Department of Pathology, Faculty of Veterinary Medicine, Beni-Suef University, Beni-Suef, Egypt. \\ ${ }^{3}$ Department of Clinical Pathology, Faculty of Veterinary Medicine, Kafr Elsheikh University, Kafr Elsheikh, Egypt.
}

Received: 2 November 2017; Accepted: 29 January 2018

\begin{abstract}
40 male albino rats were used for these experimental studies. They were divided equally into 4 groups: the first group was used as control group, the second group was given thyme extract $(300 \mathrm{mg} / \mathrm{kg} \mathrm{b}$.w $)$ by gastric intubation, the third group was given $\mathrm{CdCl}_{2}(3 \mathrm{mg} / \mathrm{kg}$ b.w) intraperitoneally while the fourth group were treated by both agents. Cadmium chloride treated rats exhibited microcytic hypochromic anemia and a significant $(\mathrm{P} \leq$ $0.05)$ increase in total leucocytic count as well as a significant increase in serum urea, creatinine and malondialdehyde. Moreover a significant decrease in serum total proteins, albumin, globulin, A/G ratio and catalase were detected. Histopathologically, marked degenerative changes were observed in renal and testicular tissues in $\mathrm{CdCl}_{2}$ treated rats along with diminished expression of $\mathrm{Bcl}-2$ (B-cell lymphoma2) in renal tissues. However, thyme extract treatment ameliorated the deleterious effects of $\mathrm{CdCl}_{2}$ on biochemical parameters, enhanced the endogenous antioxidant status, reduced lipid peroxidation and the lesions in renal tissues. Thyme extract restored the immunohistochemical expression of Bcl-2. However, hematological parameters and sever testicular degeneration were not alleviated by thyme extract. Our findings also demonstrated that thyme extract can alleviate $\mathrm{CdCl}_{2}$ nephrotoxicity via its potent antioxidant and anti-apoptotic activities.
\end{abstract}

Key words: Cadmium, nephrotoxicity, testicular, protective, oxidative stress.

\section{INTRODUCTION}

Cadmium (Cd) is one of the most serious environmental and occupational contaminants exhibiting serious health hazards to human as well as animals. People chronically exposed to low doses of $\mathrm{Cd}$, possess a wide range of tissue damage with increase incidences of cardiovascular diseases (Tellez-Plaza et al., 2013), renal damage (Wang et al., 2016), loss of nutritional elements and minerals which later resulting in diabetes and osteoporosis (Satarug et al., 2011), induce apoptosis in rat tissues including testes (Zhao et al., 2015) and reduced sperm count or even infertility (Li et al., 2016). Reactive oxygen species (ROS) and free radicals are implicated in $\mathrm{Cd}$ toxicity inducing oxidative damage in various tissues (Liu et al., 2009). Liver and kidneys are considered the most sensitive tissues to $\mathrm{Cd}$ toxicity (Ognjanovic et al., 2010). Cadmium nephrotoxicity was resulted from generating free radicals and consequently inducing cell necrosis and

Corresponding author: Dr. SAMAH ABOU ASA

E-mail address: ssabouasa@yahoo.com

Present address: Department of Pathology, Faculty of Veterinary

Medicine, Kafr Elsheikh University, Kafr Elsheikh, Egypt. apoptosis (Reyes et al., 2002; El-Sharaky et al., 2007). To date there is no effective medication to $\mathrm{Cd}$ toxicity (Matovic et al., 2011). Medicinal plants are considered a new resource for future medications (Cordero-Perez et al., 2013). Many studies have highlighted the antioxidant properties of numerous natural products against many toxicants (Shatti et al., 2011). Thymus vulgaris (thyme) is one of Laminaceae family which has a potent natural antioxidants fighting several diseases even cancers (Cerda et al., 2013). Thyme is cultivated worldwide for numerous medical purposes (Abu-Darwish et al., 2009). It is used in the treatment of gastroenteric disorders, bronchopulmonary disorders and also is used as anthelmintic, antispasmodic, sedative, antimicrobial and antifungal (El Nekeety et al., 2011). Therefore, the present study aimed to assess whether Thymus vulgaris extract could antagonize the deleterious effects of $\mathrm{Cd}$ on the hematological, biochemical, oxidative stress, histopathogical criteria in kidney as well as immunohistochemical expression of $\mathrm{Bcl}-2$ in renal tissue and its effect on the histological structure of testes. 


\section{MATERIALS AND METHODS}

\section{Collection of Thyme and preparation of the extract}

The plant material was dried at ambient temperature. The air dried plant materials were grounded to fine powder. This fine powder was soaked in adequate volume of $70 \%$ ethyl alcohol. Extraction was carried out by intermittent shaking at room temperature for 3 days. After filtration through filter paper (Whatman No. 4), the residue was re-extracted twice, then the extract was evaporated under reduced pressure using a rotatory evaporator and dried to obtain a constant weight. The residue was stored at $4^{\circ} \mathrm{C}$ until use according to Williamson et al. (1996).
2. Cadmium chloride $\left(\mathbf{C d C l}_{2}\right)$ : was purchased from (Sigma Aldrich Corporation, St. Louis, Missuria, USA).

\section{Animals and treatments:}

Forty male Albino rats 4 weeks old weighing (90100) grams, obtained from the Animal House Colony of the National Research Center, Giza, Egypt, were used in the present study. Rats were acclimatized for one week to laboratory conditions, and provided with commercial balanced diet and tap water ad-libitum throughout the experiment. Rats were randomly divided into 4 groups each consisting of 10 animals and were treated as shown in Table (1).

Table 1: Experimental groups and their treatments.

\begin{tabular}{cccccccc}
\hline \multicolumn{2}{c}{ Groups } & \multicolumn{2}{c}{ Thyme extract } & \multicolumn{2}{c}{ Cadmium chloride } \\
\hline No & Name & Route & Dose & Duration & Route & Dose & Duration \\
\hline 1 & Control & - & - & - & - & - & - \\
\hline 2 & Thyme & Intragastric & $\begin{array}{c}300 \mathrm{mg} / \mathrm{kg} \\
\text { b.w.* }\end{array}$ & 21 days & - & - & - \\
\hline 3 & $\mathrm{CdCl}_{2}$ & - & - & - & Intraperitoneal & $3 \mathrm{mg} / \mathrm{kg}$ b.w. $\begin{array}{c}5 \text { times/week } \\
\text { for 3weeks }\end{array}$ \\
\hline 4 & Thyme/Cd & Intragastric & $\begin{array}{c}300 \mathrm{mg} / \mathrm{kg} \\
\text { b.w. }\end{array}$ & $\begin{array}{c}\text { 3days before } \mathrm{CdCl}_{2} \\
\text { treatment and continued } \\
\text { daily for 3 weeks }\end{array}$ & Intraperitoneal & $3 \mathrm{mg} / \mathrm{kg}$ b.w. $\begin{array}{c}5 \text { times/week } \\
\text { for 3weeks }\end{array}$ \\
\hline
\end{tabular}

*b.w. means body weight

At the end of the experimental period, two blood samples were withdrawn from the medial canthus of the eye underlight ether anesthesia and immediately divided into aliquots one with anticoagulant for hematological examination and the other left to clot, then centrifuged for 10 minutes at 3000 r.p.m. Serum was separated and stored in eppendorf tubes at $-20^{\circ} \mathrm{C}$ to be used for biochemical analysis. After blood collection, the rats were sacrificed by decapitation. Kidneys were collected and rapidly excised from each animal, trimmed and divided into two parts; the first part was washed free of blood with $0.9 \% \mathrm{NaCl}$ solution and distilled water to assess tissue oxidative status and antioxidant indices. The second part was used for histopathological examination and immunohistochemistry. Also tissue sections from the testes were taken for histopathology.

\section{Hematological parameters:}

The aliquot contained EDTA $(1 \mathrm{mg} / \mathrm{ml})$ were used for assessing red blood cells (RBCs), hemoglobin content $(\mathrm{Hb})$, and packed cell volume (PCV), mean corpuscular volume (MCV), mean corpuscular hemoglobin $(\mathrm{MCH})$, mean corpuscular hemoglobin concentration (MCHC), total leucocytic count (TLC) and differential leucocytic count according to Feldman et al. (2000).

\section{Biochemical parameters:}

Total proteins and albumin were estimated according to Burtis and Ashwood (1999) and Dumas and Biggs (1972) respectively. Globulin concentration (Glob) in serum was measured by subtracting albumin concentration from total proteins and consequently albumin to globulin ratio (A/G) was calculated. Serum urea and creatinine were estimated spectrophotometrically (Biomerieux, Egypt) according to Fawcett and Soctt (1960) and Szasz et al. (1979) respectively.

\section{Estimation of antioxidants and lipoperoxidation markers in renal tissues:}

Only the renal tissues were used but the testicular tissues were not used. The dissected renal tissues were washed with $50 \mathrm{mM}$ sodiumphosphate-buffered saline (100 mMNa $\mathrm{HPO}_{4} / \mathrm{NaH}_{2} \mathrm{PO}_{4}, \mathrm{pH}$ 7.4) in an ice-containing medium, with $0.1 \mathrm{mM}$ EDTA to remove any $\mathrm{RBCs}$ and clots. Then tissues were homogenized in 5-10 ml cold buffer/gm tissue and were centrifuged at $5000 \mathrm{rpm}$ for $30 \mathrm{~min}$. The resulting supernatant was transferred into an eppendorf tube and was preserved at $-80^{\circ} \mathrm{C}$ into aliquots for the spectrophotometric estimation of tissue malondialdehyde (MDA) Mihara and Uchiyama (1978) and catalase (CAT) Aebi (1984). 


\section{Histopathology:}

Tissue specimens from the kidneys and testes of each animal were excised, directly fixed in $10 \%$ formalin solution, dehydrated in alcohols, cleared in xylene and embedded in paraffin blocks. Sections of $5 \mu \mathrm{m}$ thickness were obtained and stained with haematoxylin and eosin (H\&E) according to Bancroft et al. (1991).

\section{Immunohistochemistry of Bcl-2 expression in renal tissues:}

Immunohistochemical labelling of Bcl-2 was performed on the kidneys of all tested animals using $4-\mu \mathrm{m}$ thick paraffin-embedded sections. The sections were dewaxed in xylene and rehydrated in graded ethanol. For antigen retrieval, the sections were immersed in (EDTA solution, $\mathrm{pH}$ 8). Endogenous peroxidase was blocked by incubation in $0.3 \%$ hydrogen peroxide in methanol for $20 \mathrm{~min}$ at room temperature (RT). The sections were incubated with Protein Block Serum Free to prevent the binding of non-specific proteins. Immunolabelling of $\mathrm{Bcl}-2$ was performed on all samples, using anti-Bcl-2 (Santa Cruz). Sections were incubated with primary antibodies Bcl-2 1:100 overnight at $4 \circ \mathrm{C}$. Then, the sections were washed 3 times with phosphatebuffered saline (PBS), and incubated with anti-mouse IgG secondary antibodies (EnVision + System HRP; Dako) for 30 minutes at RT. The sections were washed with PBS and visualised with EnVision+ System, HRP-labelled polymer anti-rabbit (Dako®). After washing 3 times with PBS, 3,3diaminobenzidinetetrahydrochloride (Liquid DAB + Substrate Chromogen System, Dako®) was added to the sections. The sections were then washed in distilled water, counterstained with Mayer's haematoxylin, dehydrated in an alcohol gradient, cleared with xylene and mounted for examination under light microscope.

\section{Statistical analysis:}

A one way ANOVA with Duncan multiple comparison tests were used to compare significance between different experimental groups. Means and standard error for each variable were estimated. Differences between means of different groups carried out using dissimilar superscript, which showed a significance at $(\mathrm{P} \leq 0.05)$.

\section{RESULTS}

\section{Hematological findings:}

The effects of $\mathrm{CdCl}_{2}$ toxicity and the preventive effects of thyme extract on the hematological parameters are shown in Table (2). Thyme extract sole treated group revealed a significant $(\mathrm{P} \leq 0.05)$ decrease in erythrogram parameters (RBCs, HB, PCV, $\mathrm{MCV}, \mathrm{MCH})$. A significant $(\mathrm{P} \leq 0.05)$ decreases in blood parameters (RBCs, HB, PCV, MCV and $\mathrm{MCH}$ ) in $\mathrm{CdCl}_{2}$ intoxicated rats compared to the control group were detected. This picture has not been improved in rats group received both $\mathrm{CdCl}_{2}$ and thyme extract. Contrary to these results, a significant $(\mathrm{P} \leq 0.05)$ increase in TLC, neutrophil, lymphocyte and monocyte counts were observed in both $\mathrm{CdCl}_{2}$ and $\mathrm{CdCl}_{2}$ simultaneously supplemented with thyme extract compared to control group.

Table 2: Hematological parameters in different experimental groups.

\begin{tabular}{|c|c|c|c|c|}
\hline Group & & & & \\
\hline \multicolumn{5}{|l|}{ Parameters } \\
\hline $\mathrm{RBCs}\left(\mathrm{x} 10^{6} / \mu \mathrm{l}\right)$ & $7.55 \pm 0.03^{\mathrm{a}}$ & $6.24 \pm 0.08^{b}$ & $6.08 \pm 0.15^{b}$ & $5.83 \pm 0.22^{b}$ \\
\hline $\mathrm{Hb}(\mathrm{gm} / \mathrm{dl})$ & $13.5 \pm 0.15^{\mathrm{a}}$ & $11.06 \pm 0.19^{b}$ & $10.0 \pm 0.31^{\mathrm{c}}$ & $9.9 \pm 0.30^{c}$ \\
\hline $\mathrm{PCV}(\%)$ & $40.4 \pm 0.49^{\mathrm{a}}$ & $33.5 \pm 0.79^{b}$ & $30.2 \pm 1.11^{\mathrm{bc}}$ & $28.3 \pm 0.9^{c}$ \\
\hline MCV (fl) & $53.5 \pm 0.75^{\mathrm{a}}$ & $53.7 \pm 0.51^{\mathrm{a}}$ & $49.6 \pm 0.71^{\mathrm{b}}$ & $48.5 \pm 0.91^{b}$ \\
\hline $\mathrm{MCH}(\mathrm{pg})$ & $17.9 \pm 0.2^{\mathrm{a}}$ & $17.7 \pm 0.2^{\mathrm{a}}$ & $16.4 \pm 0.2^{b}$ & $16.9 \pm 0.3^{b}$ \\
\hline $\mathrm{MCHC}(\%)$ & $33.4 \pm 0.2$ & $33 \pm 0.2$ & $33.11 \pm 0.3$ & $34.9 \pm 0.3$ \\
\hline $\operatorname{TLC}\left(\times 10^{3} / \mu 1\right)$ & $7.88 \pm 0.64^{b}$ & $6.81 \pm 0.75^{b}$ & $19.3 \pm 1.12^{\mathrm{a}}$ & $18.5 \pm 1.78^{\mathrm{a}}$ \\
\hline Neutrophils $\left(\times 10^{3} / \mu 1\right)$ & $4.24 \pm 0.45^{b}$ & $3.57 \pm 0.18^{b}$ & $7.84 \pm 0.82^{\mathrm{a}}$ & $6.74 \pm 0.64^{\mathrm{a}}$ \\
\hline Lymphocytes $\left(\mathrm{x} 10^{3} / \mu \mathrm{l}\right)$ & $2.1 \pm 0.28^{b}$ & $2.02 \pm 0.48^{\mathrm{b}}$ & $8.23 \pm 0.82^{\mathrm{a}}$ & $8.9 \pm 1.11^{\mathrm{a}}$ \\
\hline Monocytes $\left(\times 10^{3} / \mu 1\right)$ & $1.53 \pm 0.17^{\mathrm{b}}$ & $1.1 \pm 0.18^{\mathrm{b}}$ & $3.26 \pm 0.3^{\mathrm{a}}$ & $2.86 \pm 0.5^{\mathrm{a}}$ \\
\hline
\end{tabular}

The data are presented as means \pm S.E. $(n=10)$. Cadmium chloride $\left(\mathrm{CdCl}_{2}\right)$, red blood corpuscles $(\mathrm{RBC})$, hemoglobin $(\mathrm{Hb})$, packed cell volume (PCV), Total leucocytic count (TLC). Different superscript letters within a row indicate significantly different mean values $(\mathrm{p} \leq 0.05)$.

\section{Biochemical parameters:}

The adverse effects of $\mathrm{CdCl}_{2}$ and the ameliorative effects of thyme on serum protein profile (total proteins, albumin, globulin and $\mathrm{A} / \mathrm{G}$ ) in control and treated rats are shown in Figure (1). Rats treated with thyme extract alone showed a non-significant change in total proteins, albumin and globulin concentrations while a significant $(\mathrm{P} \leq 0.05)$ decrease in $\mathrm{A} / \mathrm{G}$ was detected when compared to control rats. On the other hand, $\mathrm{CdCl}_{2}$ treated group represented a significant $(\mathrm{P}$ $\leq 0.05)$ decline in serum total proteins, albumin, globulins and $\mathrm{A} / \mathrm{G}$ compared with control rats. Pretreated rats with thyme extract together with $\mathrm{CdCl}_{2}$ administration showed a significant $(\mathrm{P} \leq 0.05)$ 
increase in serum total proteins, albumin and $\mathrm{A} / \mathrm{G}$ with a non-significant change in globulin concentration compared to $\mathrm{CdCl}_{2}$ treated groups. The deleterious effects of $\mathrm{CdCl}_{2}$ and the preventive effects of thyme extract on serum urea and creatinine in control and treated rats are shown in Figure (2). Thyme extract sole treated rats showed a nonsignificant change in urea and creatinine concentrations when compared to control rats. In addition, $\mathrm{CdCl}_{2}$ treated group revealed a significant $(\mathrm{P}$ $\leq 0.05)$ increase in urea and creatinine concentrations indicating nephrotoxicity compared to control rats. Pretreated rats with thyme extract along with $\mathrm{CdCl}_{2}$ administration showed a significant $(\mathrm{P} \leq 0.05)$ decreasein urea and creatinine compared to $\mathrm{CdCl}_{2}$ treated groups.
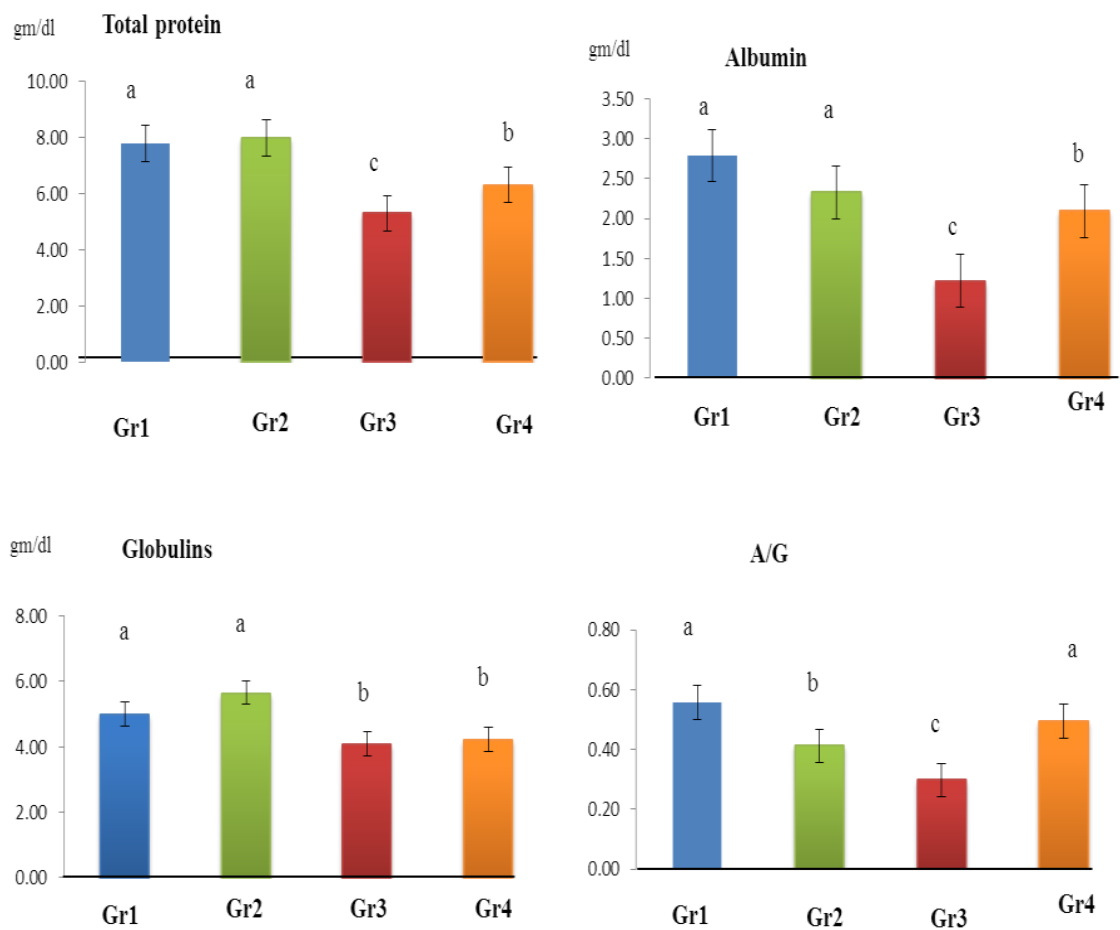

Figure 1: Serum protein profile (total protein,a lbumin,globulin and A/G) in control and treated groups .Data are expressed as mean \pm standard error (SEM). Different letters with each column indicate significant differences when compared to the control group at $\mathrm{p}<0.05 . \mathrm{A} / \mathrm{G}=$ (albumin,globulin ratio ), $\mathrm{Gr}=$ control group, $\mathrm{Gr} 2=$ Thyme extract treated group $(300 \mathrm{mg} / \mathrm{kg} \mathrm{b.w}$ ) intragastric daily for 21 days , $\mathrm{Gr} 3=$ Cadmium chloride $\mathrm{CdCl}$ ) treated group and $\mathrm{Gr} 4=(\mathrm{Thyme}(300 \mathrm{mg} / \mathrm{kg} \mathrm{b} . \mathrm{w})$ intragastric for 3 days before $\mathrm{CdCl} 2$ injection and continued along with $\mathrm{CdCl} 2$ injection ( $3 \mathrm{mg} / \mathrm{kg}$ b.w) 5 times per week for 3 weeks

Urea

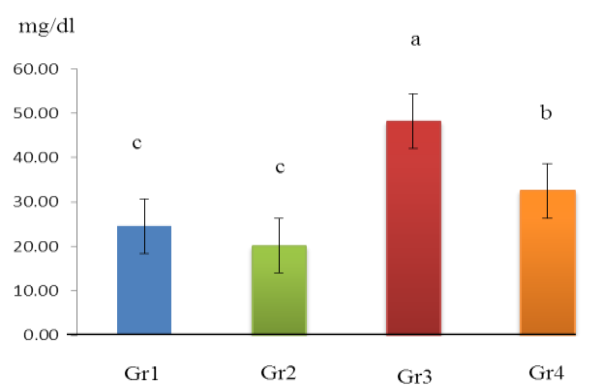

Creatinine

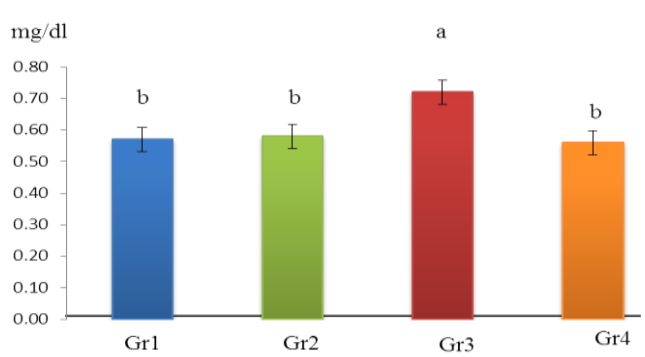

Gr3

Figure2: Serum urea and creatinine Data are expressed as mean \pm standard error (SEM). Different letters with each column indicate significant differences when compared to the control group at $\mathrm{p}<0.05$. Gr1 $=$ control group, Gr2=Thyme extract treated group $(300 \mathrm{mg} / \mathrm{kg} \mathrm{b.w})$ intragastric daily for 21 days, $\mathrm{Gr} 3=\mathrm{Cadmium}$ chloride $\mathrm{CdCl} 2)$ treated group and Gr4=(Thyme ( $300 \mathrm{mg} / \mathrm{kg} \mathrm{b} . \mathrm{w})$ intragastric for 3 days before $\mathrm{CdCl} 2$ injection and continued along with CdCl2 injection ( $3 \mathrm{mg} / \mathrm{kg}$ b.w) 5
times per week for 3 weeks.

Oxidative stress and antioxidant biomarkers:

The adverse effects of $\mathrm{CdCl}_{2}$ and ameliorative effects of thyme extract on renallipid peroxidation and antioxidant parameter catalase (CAT) are shown in Figure (3). $\mathrm{CdCl}_{2}$ treated rats revealed a significant $(\mathrm{P}<0.05)$ increase in renal MDA and a significant
$(\mathrm{P}<0.05)$ reduction in renal CAT compared to control rats. While, thyme pretreated rats along with $\mathrm{CdCl}_{2}$ administration revealed a significant $(\mathrm{P}<0.05)$ reduction in MDA level and a significant $(\mathrm{P}<0.05)$ enhancement of CAT level compared to $\mathrm{Cd}$ group. 
(A) MDA

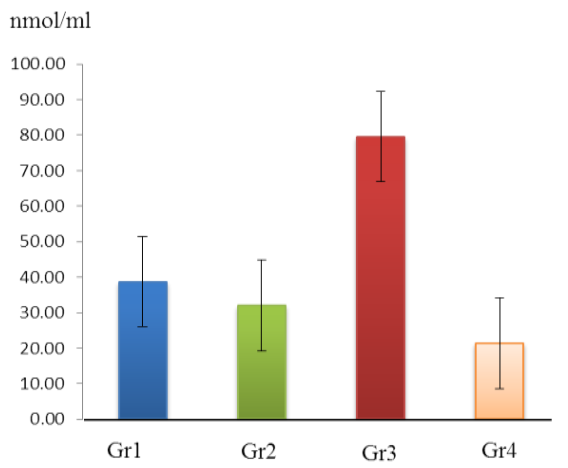

(B) CAT

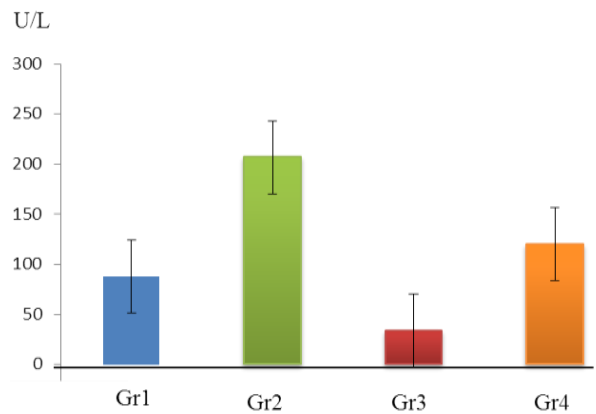

Figure3: Renal lipid peroxidation and antioxidant parameter in control and treated groups; (A) MDA malondialdehyde, (B) CAT catalase .Data are expressed as mean \pm standard error (SEM). Different letters with each column indicate significant differences when compared to the control group at $\mathrm{p}<0.05$. Gr $1=$ control group

$\mathrm{Gr} 2=$ Thyme extract treated group (300mg/ $\mathrm{kg} \mathrm{b}, \mathrm{w})$ intragastric daily for 21 days, $\mathrm{Gr} 3=$ Cadmium chloride $\mathrm{CdCl} 2$ ) treated group and $\mathrm{Gr} 4=($ Thyme $(300 \mathrm{mg} / \mathrm{kg}$ b.w) intragastric for 3 days before $\mathrm{CdCl} 2$ injection and continued along with $\mathrm{CdCl} 2$ injection ( $3 \mathrm{mg} / \mathrm{kg}$ b.w) 5 times per week for 3 weeks

\section{Histopathology:}

\section{a. Kidneys:}

Healthy control rats showed normal appearance of glomeruli and renal tubules (Fig4. A). No obvious histopathological changes were noticed in the kidneys of thyme supplemented rats. Kidneys of $\mathrm{CdCl}_{2}$ treated ratsrevealed marked congestion of inter-tubular blood vessels and glomerular capillaries (Fig4. B), hyaline casts (Fig4. C), together with marked vacuolar degeneration of tubular epithelium with nuclear pyknosis in both cortical (Fig4. D) and medullary regions (Fig5. A). Inaddition, focal areas of tubular coagulative necrosis with mild mononuclear cells infiltration (Fig5. B)were observed. Also, focal regenerative changes were detected as prominent nucleoli and basophilic cytoplasm (Fig5. C). Combined administration of thyme/Cd resulted in marked restoration of normal cortical and medullary renal parenchyma with minimal vacuolar degenerative changes of tubular epithelium (Fig5. D, E).

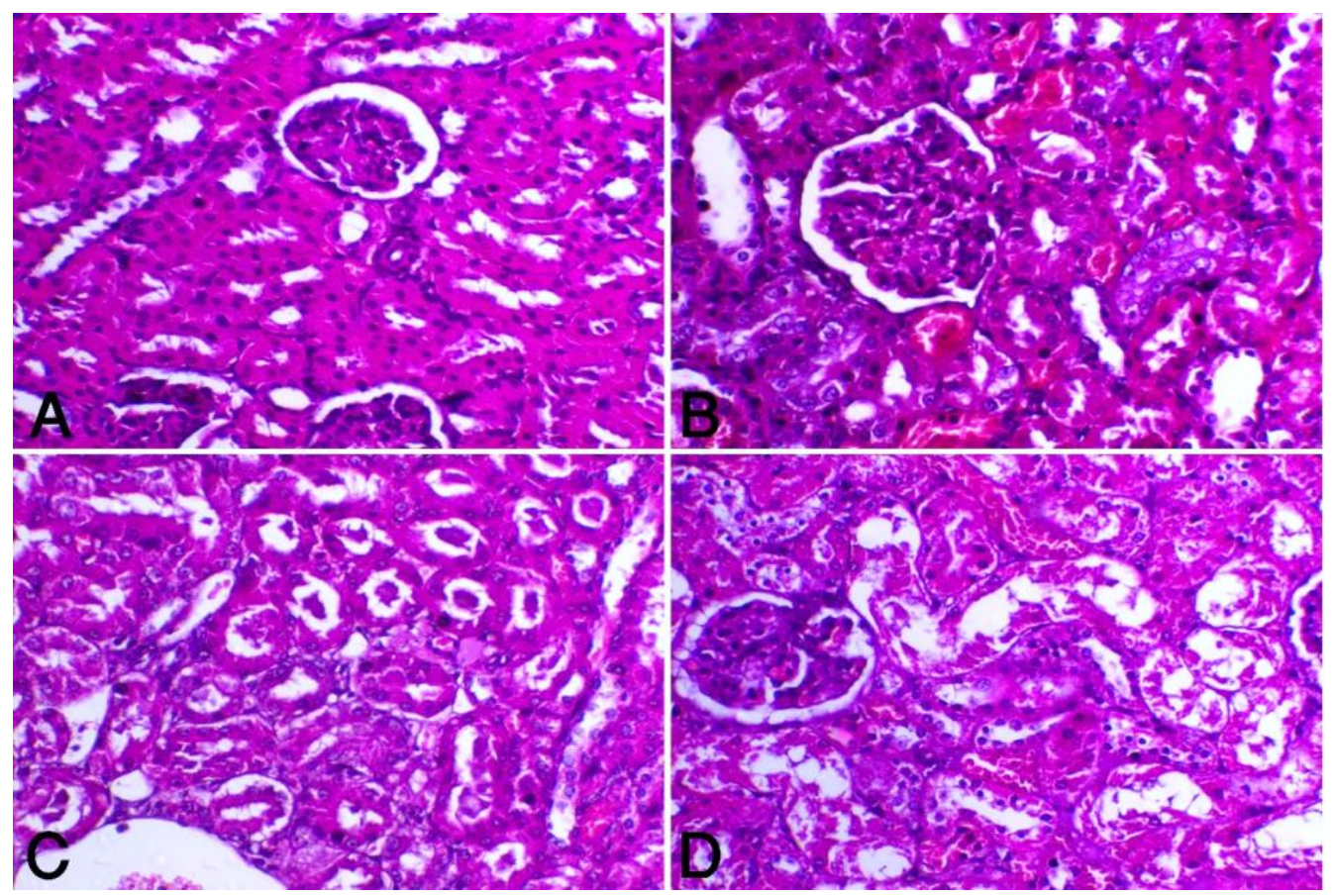

Figure (4): Histopathological changes in the kidneys of cadmium intoxicated rats.

(A): Kidney of control rats showing normal glomeruli and renal tubules (HE, 10 x20). (B): Kidney of Cd treated group showing marked congestion of inter-tubular blood vessels (HE, 10x20). (C): Kidney of Cd treated group showing marked congestion of glomerular and inter-tubular blood vessels (HE, 10x20) (D): Kidney of Cd treated group, renal cortex showing extensive vacuolar degeneration of the renal tubular epithelium with pyknotic nuclei and congestion of inter-tubular blood vessels (HE, 10x20). 


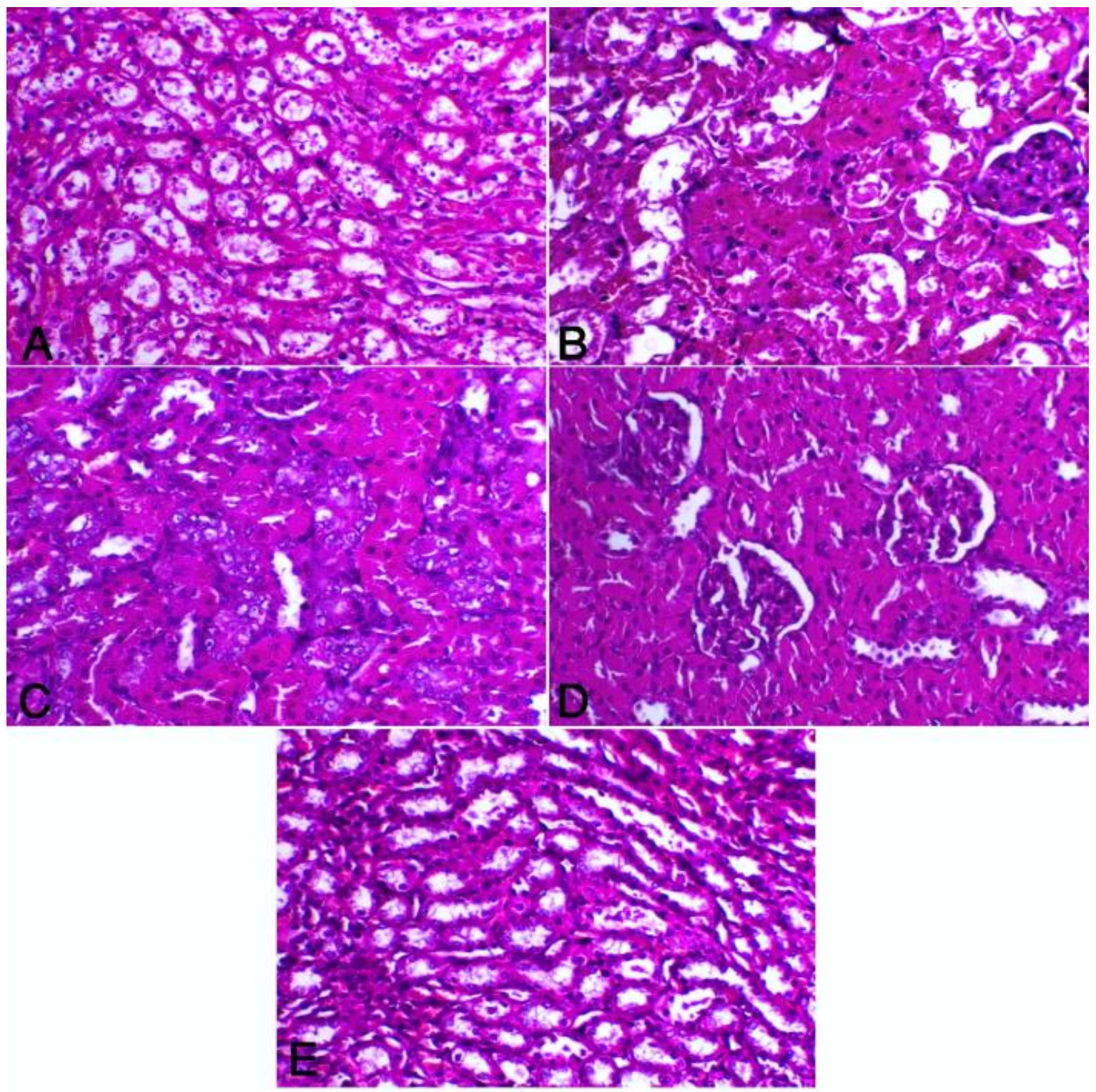

Figure (5): Histopathological changes in the kidneys of cadmium intoxicated rats and the protective effect of thyme.

(A): Renal medulla of $\mathrm{Cd}$ treated group, showing extensive vacuolar degeneration of the tubular epithelium with pyknotic nuclei (HE, $10 \times 10)$. (B): Kidney of Cd treated group showing focal area of coagulative necrosis with mononuclear cells infiltration (HE, 10x20). (C): Kidney of Cd treated group showing tubular regeneration with prominent nucleoli and basophilic cytoplasm (HE, 10x20) (D): Kidney of thyme/Cd treated group showing restoration of histological architecture of renal cortex with mild vacuolar degeneration of some tubules (HE, 10x20). (E): Renal medulla of thyme/Cd treated group showing restoration of histological architecture of renal medulla (HE, 10x20).

\section{b. Testes:}

Histological examination of the testes of the control group, showed normal testicular histology of seminiferous tubules, with all stages of spermatogenic cells and normal clusters of leydig cells (Fig6. A). No obvious histopathological changes were noticed in the testes of thyme supplemented rats. By contrast, the rats treated with $\mathrm{CdCl}_{2}$ showed reduction in testicular size on gross examination and numerous histopathological alterations in the form of: marked coagulative necrosis and the tubular epithelium are totally disorganized and necrotic with loss of lining cells (Fig6. B), vacuolation of the seminiferous tubular cells, associated with impaired spermatogenesis and dilatation of the interstitial spaces with degeneration of leydig cells (Fig6. C). However, combined administration of thyme/Cd didn't showed any improvement in the testicular architecture or restoration of normal histological structure when compared with control rats (Fig6. D). 


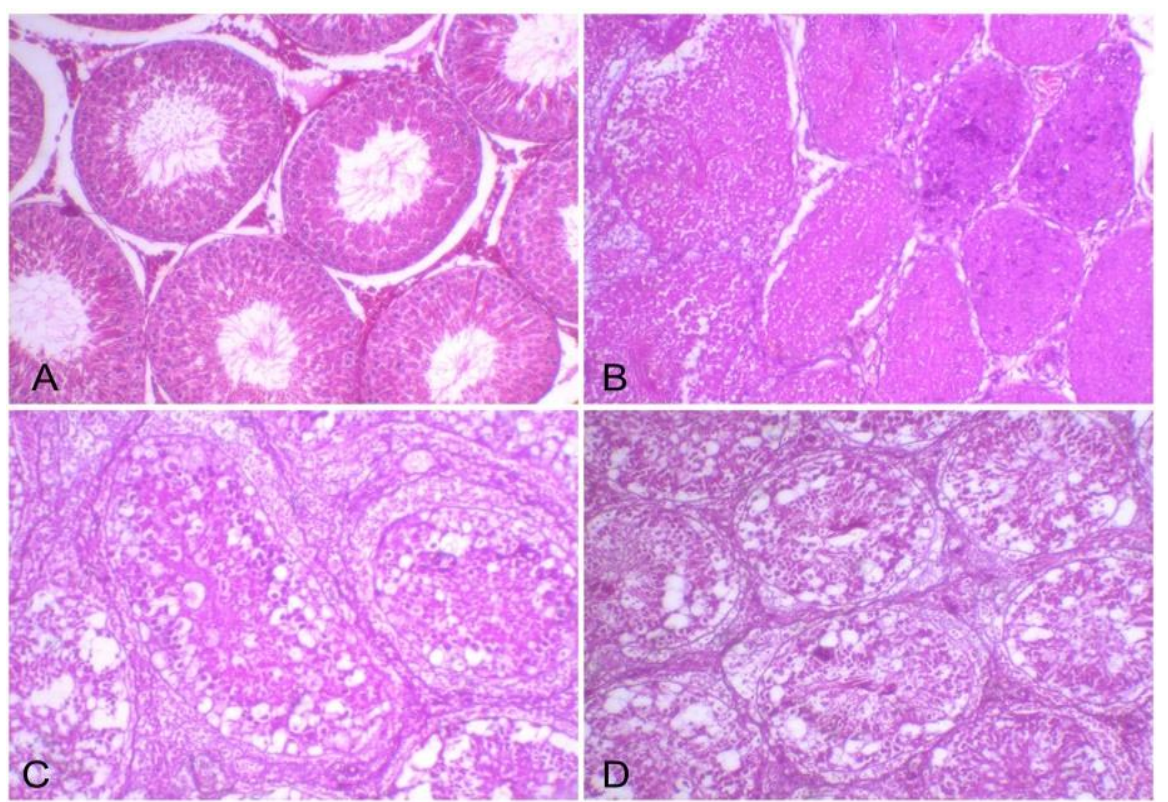

Figure (6): Histopathological changes in the testes of cadmium intoxicated rats and the protective effect of thyme.

(A): Testicular architecture in the control normal rats showing well-organized distribution of seminiferous tubules with active spermatogenesis and normal clusters of leydig cells. (HE, $10 \mathrm{x10}$ ). (B): Testes of $\mathrm{Cd}$ exposed group showing extensive coagulative necrosis of the seminiferous tubules (HE, 10x10). (C): Testes of Cd exposed group showing marked vacuolation of germinal epithelium with degeneration of leydig cells (HE, 10x20) (D): Testes of thyme/Cd treated group showing marked vacuolation of germinal epithelium (HE, 10x20).

\section{Immunohistochemistry:}

Immunolabelling of Bcl-2 was observed in the cytoplasm of renal tubular epithelial cells of control rats (Fig7. A). Very weak expression of Bcl-2 was observed in the cytoplasm of few tubular cells in both cortical and medullary regions in $\mathrm{Cd}$ intoxicated rats
(Fig7. B, C). However, most of renal tubular epithelial cells in the cortical and medullary regions were strongly expressed $\mathrm{Bcl}-2$ in rats received thyme/Cd when compared with $\mathrm{CdCl}_{2}$ intoxicated rats (Fig7. D, E).

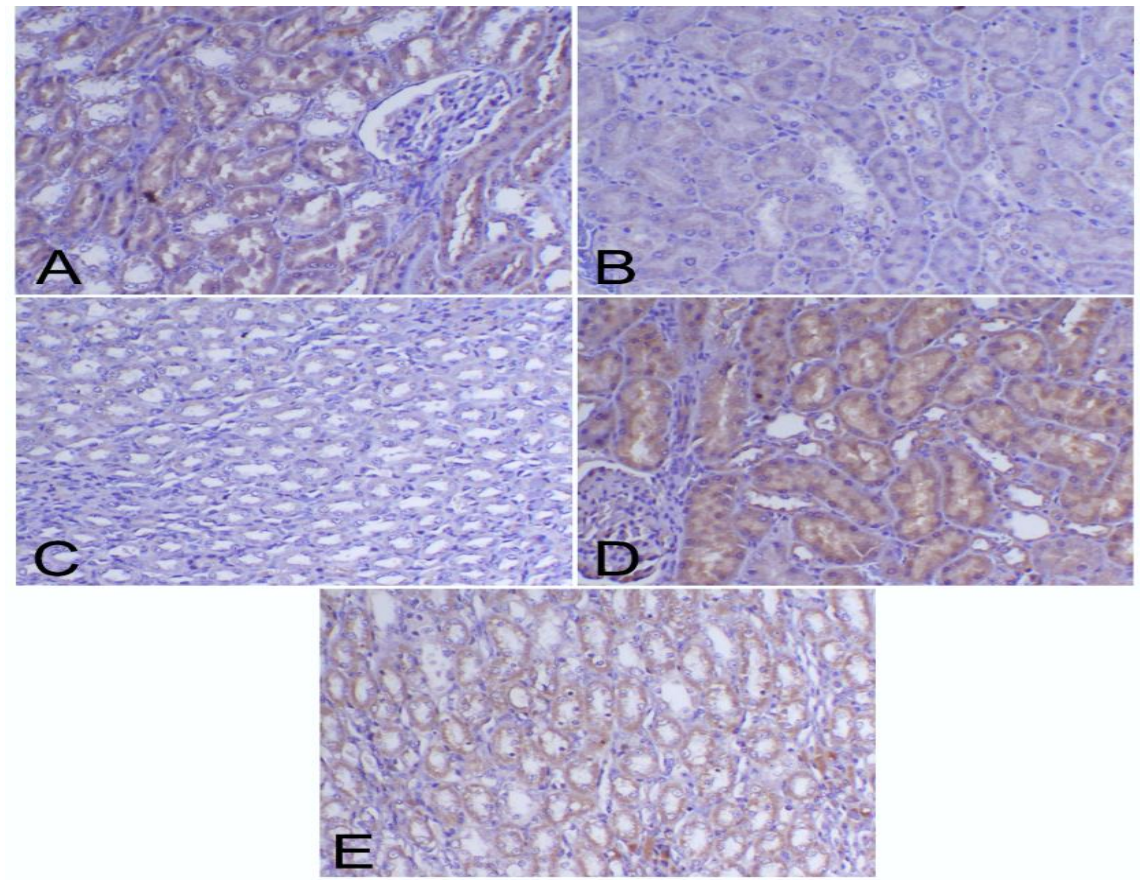

Figure (7): Immunohistochemical expression of Bcl-2 in the kidneys of $\mathrm{Cd}$ intoxicated rats.

(A): Kidney of control group showing immunoreactivity of Bcl-2 in the cytoplasm of renal tubular cells (IHC, 10x20). (B): Renal cortex of $\mathrm{Cd}$ treated group, showing very weak immunoreactivity in the cytoplasm of few renal tubular cells (IHC, 10x20). (C): Renal medulla of Cd treated group, showing very weak immunoreactivity in few of renal tubular cells (IHC, 10x20). (D): Kidney of thyme/Cd treated rats, renal cortex showing strong cytoplasmic immunoreactivity of Bcl-2 in all renal tubular cells. (IHC, 10x20). (E): Renal medulla of thyme/Cd treated rats, showing strong cytoplasmic immunoreactivity of Bcl-2 in all renal tubular cells (IHC, $10 \times 20$ ). 


\section{DISCUSSION}

Cadmium $(\mathrm{Cd})$ is a naturally occurring heavy metal causing severe risks to human health (Krichah et al., 2003). Acute Cd exposure producedtoxicity to the lung, liver, testes, and brain (Shimaa and Emad, 2014). Cd is unique among other heavy metals because of its ability to induce toxicity at a very low dosage, long biologic half -life and its low excretion rate from the body (Kaoud and Mekawy, 2011). About one-third of the absorbed $\mathrm{Cd}$ is stored in the kidneys directly after gastrointestinal or pulmonary absorption (Jarup et al., 1998b). Hematopoietic system is one of the most sensitive system to evaluate the toxicity of environmental pollutants and drugs in humans as well as animals (Yuan et al., 2014). The results of the existent study revealed a significant $(\mathrm{P}<0.05)$ reduction in the erythrogram parameters (RBCs, Hb, PCV, MCV and $\mathrm{MCH}$ ) in only thyme treated group, $\mathrm{CdCl}_{2}$ intoxicated group and rat group received both of them. It is likely that microcytic hypochromic anemia developed during the period of $\mathrm{CdCl}_{2}$ exposure due to decrease of the intestinal iron (Fe) absorption by $\mathrm{Cd}$ in line with countless studies showing thereduction of $\mathrm{Fe}$ levels in the liver and other organs, when animals are exposed to nutritional Cd loading (Kozlowska et al., 1993 and Elsenhans et al., 1994). Several studies have provided indication that $\mathrm{Cd}$ hinders $\mathrm{Fe}$ absorption through the intestine, probably by competing with $\mathrm{Fe}$ in the absorption process (Schafer and Elsenhans, 1985 and Kozlowska et al., 1993). Additionally, the anemia induced by $\mathrm{Cd}$ may be due to its accumulation in kidney, spleen and liver which might suppress the action of these hematopoietic tissues (Ashour, 2014). On the other hand, the anemia developed during the period of exposure to either thyme alone or $\mathrm{CdCl}_{2}$ with thyme extract can be explained by presence of tannins which are a complex group of polyphenolic compounds that are existing in many species usually consumed by ruminants (Fruto et al., 2004). It is well known that thymol (as a naturally occurring phenolic monoterpene) found in thyme oil extracted from Thymus vulgaris is rich source by Tannins which reduces $\mathrm{Fe}$ absorption when involved in the diet at extraordinary levels (South and Miller, 1998). Regarding to the leukogram in the present work, $\mathrm{CdCl}_{2}$ exposure led to leukocytosis with absolute neutrophilia, lymphocytosis and monocytosis which is in the agreement with (Djokic et al., 2014) who approved that $\mathrm{Cd}$ intoxicated rats exhibited neutrophilia and monocytosis which is as a result of induced bone marrow neutrophils release and mobilization as well as relocation from tissues into circulating neutrophils under inflammatory conditions. Also, Cassatella (1999) referred that granulocytes are also a source of cytokines that might modulate local tissue inflammatory reaction. The observed lymphocytosis are in harmony with the investigations of Oshawa and Kawai (1981) who explained lymphocytosis as an enhanced lymphopoiesis and/or an efflux of lymphocytes from the lymphopoietic loci after s.c injection of sub-lethal doses of $\mathrm{CdCl}_{2}$ in mice $(0.0625$ to $2 \mathrm{mg} / \mathrm{kg}$ ) for $1-7$ weeks and daily inhalation of cadmium oxide fumes in rats $(0.1$ and $1 \mathrm{mg} / \mathrm{m} 3)$ for 4 weeks. Similarly, Harada et al. (1979) reported that people occupationally exposed to $\mathrm{Cd}$ have possessedan increase in the large lymphocyte count. This was referred to the cytological shift correlated to a concomitant decrease in the number of small lymphocyte. This cytological shift was due to transformation of lymphocytes by $\mathrm{Cd}$ as shown by in vitro lymphocyte culture (Shenker et al., 1977), and or by the compensatory supply of blast-like lymphocytes from lymphoid tissues resulting from primary destruction of peripheral lymphocytes by $\mathrm{Cd}$. The current biochemical findings demonstrated that thyme sole supplemented group in significantly changed serum total protein and albumin are in line with (Toghyani et al., 2010) who verified that thyme powder didn't affect serum protein and albumin of broiler chicks. On the other hand, the reduction in serum total proteins in $\mathrm{CdCl}_{2}$ sole treated group which may indicate disorders in protein synthesis and metabolism as a result of individual actions or interactions of the complex metal constituents (Olivier et al., 2005). It has been similarly described that $\mathrm{Cd}$ exposed rats showed reduced serum total proteins with increased serum urea and creatinine due to functional impairment to kidney (Morowati, 2001). Also, it has been reported that renal injury induced by $\mathrm{Cd}$ is initially presents as tubular proteinuria, which progresses on continuous exposure (Pinot et al., 2000). The decrease in serum total proteins, seems to be attributed to a decrease in albumin, which also indicates that $\mathrm{Cd}$ induced liver and kidney damage. This is consistent with the work of Shatti, (2011) who reported a rise in creatinine level which indicated renal tubular damage due to $\mathrm{Cd}$ induced nephrotoxicity. Several studies have documented that the $\mathrm{Cd}$ induced tubular proteinuria and damage is permanent even though exposure ends (Jarup and Elinder, 1993 and Jarup et al., 2000). Also, the significant increase in serum urea and creatinine levels $(\mathrm{P}<0.05)$ in rats treated with $\mathrm{Cd}$ which agreed with Nasim et al. (2015) who intraperitoneally administered $\mathrm{Cd} 1 \mathrm{mg} / \mathrm{kg}$ for 21 days where creatinine and protein levels were decreased while levels of urea, $\mathrm{Na}$ and $\mathrm{K}$ were increased as a result of $\mathrm{Cd}$ exposure. Moreover, $\mathrm{CdCl}_{2}$ treatment mediates oxidative stress which evidenced by elevated renal MDA levels and depleted enzymatic antioxidant defenses, including CAT. The increased renal lipid peroxidation (LPO) in Cd intoxicated rats may be due to a significant $(\mathrm{P} \leq 0.05)$ inhibition of the activities of free radical capturing enzymes such as CAT. Our results are supported by the findings of Schauder et al. (2010) who identified that CAT is acrucial antioxidant enzyme having heme as an active location prosthetic group, $\mathrm{Cd}$ is known to diminish iron integration and hinder with heme biosynthesis. 
Similarly, Ansari et al. (2017) who reported that Cd that has been accumulated in the kidney generates ROS that causes oxidative stress, inflammation, apoptosis and glomerular dysfunction. On the same line Elkhadragy and Abdel Moneim, (2017) detected that the deleterious effects of $\mathrm{Cd}$ may be related to its capacity to generate ROS that injure the kidney via two pathways; including its capability to increase LPO and deplete ROS scavenging capability. LPO is a noticeable marker of oxidative stress and it is known to rise cellular content of epoxides, hydroperoxides, and MDA which in sequence can react with cellular proteins, DNA and RNA initiating renal tissue damage (Kehrer and Klotz, 2015). Our findings revealed that the improvement of renal functional parameters to be closer to control values indicates that thyme extract could alleviate the plasma membrane and induce cellular healing. The highest values of free radical scavenging activity of thyme extract could be due to its higher content of phenolic components ( $\mathrm{Lu}$ and Foo, 2001). Our results indicate that thyme extract can safeguard the ordinary capacity of the kidney and protect against $\mathrm{Cd}$ induced injury. In the current study, $\mathrm{CdCl}_{2}$ treated rats showed marked congestion of inter-tubular blood vessels and capillaries of glomerular tufts, hyaline casts as well as marked vacuolar degeneration of tubular epithelium with nuclear pyknosis. In addition to, focal areas of tubular coagulative necrosis accompanied with slight mononuclear cells infiltration. Also, multiple focal areas of tubular regeneration with aprominent nucleoli and basophilic cytoplasm were detected. Combined administration of thyme/Cd, thyme resulted in normalize kidney function tests with marked restoration of renal parenchyma to normal histological appearance when compared with control rats which supported by significant decline in MDA and significant increase in CAT levels. Subsequen tregeneration of proximal tubular cells happens after $\mathrm{Cd}$ exposure in rats and dogs (Iwai and Matsuno, 1991). Moreover, (Liu et al., 2000) validated that Cd exposure induces apoptosis and subsequent renewal of the renal tubular epithelium in chicken kidneys. The observation of multiple foci of tubular regenerating foci in the existing study were in bargain with Tanimoto et al. (1993) who noted that proliferating proximal tubular cells (tubular regeneration) is a part of the response to apoptotic injury. Additionally, exposure to $\mathrm{CdCl}_{2}$ leads to a decrease in the activities of antioxidant enzymes, such as superoxide dismutase (SOD) and CAT (Jurczuk et al., 2004). The current observed lesions were supported by increasing renal MDA and depletion of CAT which is in agreement with Fouad and Jersat, (2011) who also reported a kidney damage, with increased MDA levels, and a decline in GSH and CAT activities after $\mathrm{Cd}$ exposure. B-cell lymphoma 2 (Bcl-2) family protein members are importantly wellknown to adjust the release of apoptosis activating factors that Bcl-2 to Bax ratio controls cell survival or death (Oltval et al., 1993). Subsequently, changes in the Bax and Bcl-2 expression activates caspase-3 initiating apoptotic processes (Rana, 2008). In the current study, $\mathrm{Cd}$ administrated group showed very weak immunoreactivity of $\mathrm{Bcl}-2$ in the glomerular and tubular epithelium which indicates the apoptotic effect of $\mathrm{Cd}$. On the other hand, thyme/Cd combined administration resulted in restoring $\mathrm{Bcl}-2$ expression where almost all of renal tubular epithelial cells showed intense cytoplasmic immunoreactivity with some reactivity in glomerular cells which strongly support the antiapoptic properties of thyme. To the best of our knowledge, currently there is no report about the effects of thyme/Cd on the expression of $\mathrm{Bcl}-2$ in renal tissues. There is a stout indication suggests that the harmful effect of $\mathrm{Cd}$ on testicular function, even though very minimal concentrations, making testes the most vulnerable organ to $\mathrm{Cd}$ toxicity (Blanco et al., 2010). Also $\mathrm{CdCl}_{2}$ caused sterility in adult rats, mice, and hamsters via wide spread degeneration of spermatogenic epithelium (De Souza Predes et al., 2010; Ponnusamy and Pari, 2011). In the current study, histopathological examination of testes in $\mathrm{Cd}$ treated rats showed extensive necrosis and vacuolation of the seminiferous tubular epithelium, associated with impaired spermatogenesis. These findings are strongly agreed with Adel et al. (2016) who administered $\mathrm{CdCl}_{2}$ (5 $\mathrm{mg} / \mathrm{kg}$ b.w) which induced congestion, edema in the interstitium, irregularities in arrangement of the epithelial lining of the seminiferous tubules, and accumulation of the degenerated and sloughed spermatogenic cells in the center of the seminiferous tubules. The observed testicular damage in the current study may due to that the plasma membrane of spermatozoa contains large amounts of polyunsaturated fatty acid, which is more liable to the ROS arising from Cd toxicity (Alvarez and Storey, 1995). However, combined administration of thyme/Cd showed no improvement in the testicular tissue when compared with control rats. From these findings, supplementary studies are needed to precisely assess the protective role of thyme against testicular damage induced by $\mathrm{Cd}$ by using grading doses of thyme extract where the current used dose of thyme, showed no protective effect, which may be small to counteract the testicular damage induced by Cd.

\section{CONCLUSION}

Cadmium had a deleterious effect on the renal hematological, biochemical, anti-oxidative activities beside it cause toxic nephritis and degenerative orchitis. Thymus vulgaris extract is protecting against $\mathrm{Cd}$ nephrotoxicity as it had antioxidant and antiapoptotic activities. This is the first study to exhibit the effect of Thymus vulgaris on the expression of Bcl-2 in the renal tissue. In the current study, thyme couldn't alleviate the induced testicular damage which may be due to complete spermatogenesis in the adult rat is approximately 40 days which isn't existing in the current study duration. So further studies by 
carrying out experimental design of long duration sufficient for completing spermatogenesis along with using grading doses of thyme are needed to assess its protective effect against testicular damage together with estimation of testosterone level, acid and alkaline phosphatase activities and oxidative stress markers. Finally, we recommend eating diets containing amounts of thyme to counteract the nephrotoxic effect of the possibly exposed $\mathrm{Cd}$.

\section{REFERENCES}

Abu-Darwish, M.S.; Dieyeh, Z.H.; Mufeed, M. and Altawaha, A.M. (2009): Trace elementcontents and essential oil yields from wild thyme plant (Thymus serpyllum L.) grown at different natural variable environments. J. Food Agri. Environ.7, 5:920-924.

Adel, A.; Zafer, S.A.; Ayman, S.; Tulip, A.; Mohamed, M.S. and Hossam, A. (2016): Protective effect of grape seed extract against cadmium-induced testicular dysfunction. Mol. Med. Rep. 13, 4: 3101-3109.

Aebi, H. (1984): Catalase in vitro. Methods Enzymol. 105: 121-126. doi:10.1016/S0076- 76879 (84)05016-3.

Alvarez, J.G. and Storey, B.T. (1995): Differential incorporation of fatty acids into and peroxidative loss of fatty acids from phospholipids of human spermatozoa. Mol. Reprod. Dev. 42, 3: 334-346.

Ansari, M.A.; Raish, M.; Ahmad, A.; Alkharfy, K.M.; Ahmad, S.F.; Attia, SM.; Alsaad, A.M. and Bakheet, S.A. (2017): Sinapic acid ameliorate cadmium-induced nephrotoxicity: in vivo possible involvement of oxidative stress, apoptosis, and inflammation via NF-kappa Bdownregulation. Environ Toxicol Pharmacol. 51:100-107.

Ashour, T.H. (2014): Preventative effects of caffeic acid phenyl ester on cadmium intoxication induced hematological and blood coagulation disturbances and hepatorenal damage in rats. ISRN Hematol.1-7.

Bancroft, J.D.; Stevens, A. and Tumer, D. (1991): Theory and practice of histological techniques; 3rd. Ed. Churchill livingstone; Medical Division of Longman Group. New York.

Blanco, A.; Moyano, R.; Molina, A.M.; Blanco, C.; Flores-Acuna, R.; Garcia-Flores, J.R.; Espada, M. and Monterde, J.G. (2010): Preneoplastic and neoplastic changes in the leydig cells population in mice exposed to low doses of cadmium. Toxicol. Ind. Health. 26, 451-457.

Burtis, C. and Ashwood, E.R. (1999): In Tietz Text book of Clinical Chemistry. Edition. W.B. Saunders Co; p: 523.

Cassatella, M.A. (1999): Neutrophil derived proteins: selling cytokines by the pound. Adv. Immunol. 73, 369-509.

Cerda, A.; Martinez, M.E.; Soto, C.; Poirrier, P.; Perez-Correa, J.R.; Vergara-Salinas, J.R. and
Zuniga, M.E. (2013): The enhancement of antioxidant compounds extracted from Thymus vulgaris using enzymes and the effect of extracting solvent. Food Chem. 139: 138143.

Cordero-Perez, P.; Torres, G.L.; Aguirre, G.M.; Camara, L.C.; Garza, F.; Alarcon, G.; Zapata-Chavira, H.; Sotelothe, G.M.; TorresEsquivel, C.N.; Sanchez-Fresno, E.; CantuSepulveda, D.; Gonzalez, S. G.; BernalIt, R.J. and Munoz-Espinosa, L.E. (2013): Hepatoprotective effect of commercial herbal extracts on carbon tetrachloride-induced liver damage in Wistar rats. Pharmacognosy Res. 5: 150-156.

De Souza Predes, F.; Diamante, M.A. and Dolder, H. (2010): Testis response to low doses of cadmium in wistar rats. Int. J. Exp. Pathol. 91, 125-131

Djokic, J.; Ninkov, M.; Mirkova, I.; Popov, A.; Aleksandrov, L. and Zolotarevskib, D. (2014): Differential effects of cadmium administration on peripheral blood granulocytes in rats. Environ. Toxicol. Pharmacol. 37: 210-219.

Dumas, B.T. and Biggs, H.G. (1972): In Standard Methods of Clinical Chemistry, 7: 175. Academic Press, New York.

El Nekeety, A.A.; Mohamed, S.R.; Hathout, A.S.; Hassan, N.S.; Aly, S.E. and Abdelwahhab, M.A. (2011): Antioxidant properties of Thymus vulgaris oil against aflatoxin-induce oxidative stress in male rats. Toxicon. 57: 984991.

Elkhadragy, M.F. and Abdel Moneim, A.E. (2017): Protective effect of Fragaria ananassa methanolic extract on cadmium chloride $(\mathrm{CdCl} 2)$-induced hepatotoxicity in rats. Toxicol. Mech. Methods. 27,5: 335-345.

Elsenhans, B.; Kolb, K.; Schumann, K. and Forth, W. (1994): The longitudinal distribution of cadmium, zinc, copper, iron, and metallothionein in the small intestinal mucosa of rats after administration of cadmium chloride. Biol. Trace Elem. Res. 41:31-46.

El-Sharaky, A.S.; Newairy, A.A.; Badreldeen, M.M.; Eweda, S.M. and Sheweita, S.A. (2007): Protective role of selenium against renal toxicity induced by cadmium in rats. Toxicology. 235:185-193.

Fawcett, J.K. and Scott, J.E. (1960): A rapid and precise method for the determination of urea. J. Clin. Pathol. 13:156-159.

Feldman, B.F.; Zinkl, J.G. and Jain, V.C. (2000): Schalm's Veterinary Hematology 5th ed. Lippincott Williams and Wilkins. Canada.

Fouad, A.A. and Jresat, I. (2011): Protective effect of telmisartan against cadmium induced nephrotoxicity in mice. Life Sci. 89:29-35.

Frutos, P.; Hervas, G.; Giraldez, F.J. and Mantecon, A.R. (2004): Review. Tannins and ruminant nutrition. Spanish J. Agri. Res 2:191-202. 
Harada, A.; Hirota, M.; Shibuya, Y. and Konu, K. (1979): Health Examination on Cadmium Workers: A Report on Itai-Itai Disease and Chronic Cadmium Poisoning to Japanese Agency of Environment," pp. 86-99. Kankyo Hoken Report 45.

Iwai, T and Matsuno, K. (1991): An ultrastructural study on the damage of the renal proximal tubules of rats by cadmium administration. J. Med. Soc. Toho.37:757-771.

Jarup, L. and Elinder, C.G. (1993): Incidence of renal stones among cadmium exposed battery workers. Br. J. Med. 50:598-602.

Jarup, L.; Berglund, M.; Elinder, C.G.; Nordberg, G. and Vahter, M. (1998b): Health effects of cadmium exposure: a review of the literature and a risk estimate. Scand. J. Work Environ. Health. 24, 1: 7-51.

Jarup, L.; Hellstrom, L.; Alfven, T.; Carlsson, M.D.; Grubb, A. and Persson, B. (2000): Low level exposure to cadmium and early kidney damage: the OSCAR study. Occup. Environ. Med.57, 10: 668-672.

Jurczuk, M.; Brzoska, M.M.; Moniuszko, J.J.; Galazyn, S.M. and Kulikowska, K.E. (2004): Antioxidant enzymes activity and lipid peroxidation in liver and kidney of rats exposed to cadmium and ethanol. Food Chem. Toxicol. 42: 429-438.

Kaoud, H.A. and Mekawy, M.M. (2011): Effect of Cadmium Pollution on Neuromorphology and Function of brain in Mice Offspring. Nature and Science. 9, 4: 28-35.

Kehrer, J.P. and Klotz, L.O. (2015): Free radicals and related reactive species as mediators of tissue injury and disease: implications for health. Crit. Rev. Toxicol. 45, 9: 765-798.

Kozlowska, K.; Brzozowska, A.; Sulkowska, J. and Roszkowski, W. (1993): The effect of cadmium on iron metabolism in rats. Nutr. Res.13:11631172.

Krichah, R.; Ben Rhouma, K.; Hallegue, D.; Tebourbi, O.; Couton, D. and Sakly, M. (2003): Acute Cadmium Administration Induces Apoptosis in Rat Thymus and Testicle; but not Liver. Polish J. Environ. Stud.12, 5:589-594.

Li, R.; Luo, X.; Li, L.; Peng, Q.; Yang, Y.; Zhao, L.; Ma, M. and Hou, Z. (2016): The protective effects of melatonin against oxidatives and inflammation induced by acute cadmium exposure in mice testis. Biol. Trace element Res. 170:152-64.

Liu, J.; Qu, W. and Kadiiska, M.B. (2009): Role of oxidative stress in cadmium toxicity and carcinogenesis. Toxicol. Appl. Pharmacol. 238:209-214.

Liu, Y.; Liu, J.; Habeebu, S.; Waalkes, M. and Klaassen, C. (2000): Metallothionein I/II null mice are sensitive to chronic oral cadmium- induced nephron-toxicity. Toxicol. Sci. 57: 167-176.

Lu, Y. and Foo, L.Y. (2001): Antioxidant activity of polyphenols from sage (Salvia of ficinalis). Food Chem. 75:197-202.

Matovic, V.; Buha, A.; Bulat, Z. and Dukic-Cosic, D. (2011): Cadmium toxicity revisited: focus on oxidative stress induction and interactions with zinc and magnesium. Arhiv. Zahigijenu. Rada. I Toksikologiju. 62: 65-76.

Mihara, M. and Uchiyama, M. (1978): Determination of malonaldehyde precursor in tissues by thiobarbituric acid test. Anal. Biochem. 86, 1: 271-278.

Morowati, M. (2001): Biochemical and histopathological changes in serum creatinine and kidney induced by inhalation of Thimet (phorate) in male Swiss Albino mouse, Mus Musculus. Environ. Res. 87: 31-36.

Nasim, B.; Ali, A.M.; Kahin, S. and Somaye, B. (2015): The Protective Roles of Zinc and Magnesium in Cadmium-Induced Renal Toxicity in Male Wistar Rats. Iran. J. Toxicol. 8, 27: 1160-1167.

Ognjanovic, B.I.; Markovic, S.D.; Ethordevic, N.Z.; Trbojevic, I.S.; Stajn, A.S. and Saicic, Z.S. (2010): Cadmium-induced lipid peroxidation and changes in antioxidant defense system in the rat testes: protective role of coenzyme Q (10) and vitamin E. Reprod. Toxicol. 29:191197.

Olivier, B.; Gregory, J.; Michel, T. and Marc, C. (2005): Effect of heavy metals on, and handling by the kidney. Nephron. Physiol. 99: 105-110.

Oltval, Z.N.; Milliman, C.L. and Korsmeyer, S.J. (1993): Bcl-2 heterodimerizes in vivo with a conserved homolog, Bax, that accelerates programed cell death. Cell. 74:609-619.

Oshawa, M. and Kawai, M. (1981): Cytological shift in lymphocytes induced by cadmium in miceand rats. Environ. Res. 24: 192-200.

Pinot, F.; Kreps, S.E.; Bachelet, M.; Hainaut, P.; Bakonyi, M. and Polla, B.S. (2000): Cadmium in the environment: sources, mechanisms of biotoxicity, and biomarkers. Rev. Environ. Health. 15, 3: 299-323.

Ponnusamy, M. and Pari, L. (2011): Protective role of diallyltetrasulfide on cadmium-induced testicular damage in adult rats: A biochemical and histological study. Toxicol. Ind. Health. 27, 407-416.

Rana, S.V.S. (2008): Metals and apoptosis: recent developments. J. Trace. Elem. Med Bio. 22: 262-284.

Reyes, J.L.; Lamas, M.; Martin, D.; Namorado, C.M.; Islas, S. and Luna, J. (2002): The renal segmental distribution of claudins changes with development. Kidney Int. 62:476-487.

Satarug, S.; Garrett, S.H.; Sens, M.A. and Sens, D.A. (2011): Cadmium, environmental exposure, 
and health outcomes. Ciencia and saudecoletiva. 16: 2587-2602.

Schafer, S. and Elsenhans, B. (1985): Iron retention and distribution in the cadmium-induced iron deficiency. Ecotoxicol. Environ. Safety.10: 128-141.

Schauder, A.; Avital, A. and Malik, Z. (2010): Regulation and gene expression of heme synthesis under heavy metal exposure-review. J. Environ. Pathol. Toxicol. Oncol. 29, 2: 137158.

Shati, A.A.; Elsaid, F.G. and Hafez, E.E. (2011): Biochemical and molecular aspects of aluminium chloride-induced neurotoxicity in mice and the protective role of Crocus sativus L. extraction and honey syrup. Neuroscience. 175:66-74.

Shatti, A. A. (2011): Effects of Origanummajorana L. On cadmium induced hepatotoxicity and nephrotoxicity in albino rats. Saudi Med. J. 32, 8: $15-20$.

Shenker, B.J.; Matarazzo, W. J.; Hirsch, R.L. and Gray, I. (1977): Trace metal modification of immunocompetence. Cell. Immunol. 34: 19-24.

Shimaa, A.E. and Emad, A.H. (2014): Clinicopathological studies of Thymus vulgaris extract against cadmium induced hepatotoxicity in Albino Rats. Glob. J. Pharmacol. 8, 4: 501-509.

South, P.K. and Miller, D.D. (1998): Iron binding by tannic acid: Effects of selected ligands. Food Chem. 63:167-172.

Szasz, G.; Borner, U.; Busch, E.W. and Bablok, W. (1979): Enzymatic assay of creatinine in serum: comparison with Jaffe metods. J. Clin. Chem. Clin. Biochem. 17:683-687.
Tanimoto, A; Hamada, T. and Koide, O. (1993): Cell death and regeneration of renal proximal tubular cells in rats with subchronic cadmium intoxication. Toxicol Pathol. 21: 341-352.

Tellez-Plaza, M.; Jones, M.R.; Dominguez-Lucas, A.; Guallar, E. and Navas-Acien, A. (2013): Cadmium exposure and clinical cardiovascular disease: a systematic review. Current atherosclerosis reports. 15, 10: 15: 356 .

Toghyani, M.; Tohidi, M.; Gheisari, A.A. and Tabeidian, S. (2010): Performance, immunity, serum biochemical and hematological parameters in broiler chicks fed dietary thyme as alternative for an antibiotic growth promoter. African J. Biotechnol. 9,40: 68196825.

Wang, H.; Yu, Y.; Li, J.; Wu, H.; Sun, J. and Zhang, Z. (2016): Cadmium stimulates mouse skin fibroblast apoptosis by affecting intracellular homeostasis. Drug and chemical toxicology. 1:74-84.

Williamson, E.M.; Okpako, D.T. and Evans, F.J. (1996): Pharmacological methods in phytotherapy research. In: Selection, Preparation and Pharmacological Evaluation of Plant Materials, John Wiley, Chichester. 1, 184-186.

Yuan, G.; Dai, S. and Yin, Z. (2014): Toxicological assessment of combined lead and cadmium: acute and sub-chronic toxicity study in rats. Food Chem. Toxicol. 65: 260-268.

Zhao, H.; Liu, W.; Wang, Y.; Dai, N.; Gu, J.; Yaun, Y.; Liu, X.; Bian, J. and Liu, Z.P. (2015): Cadmium induces apoptosis in primary rat osteoblasts through caspase and mitogenactivated protein kinase pathways. J. Vet. Sci.16: 297-306.

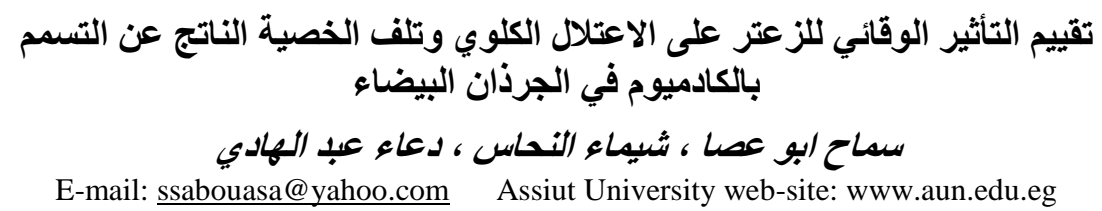

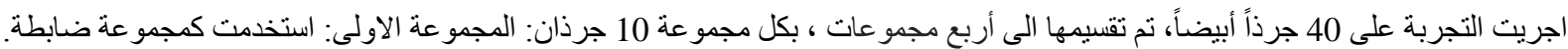

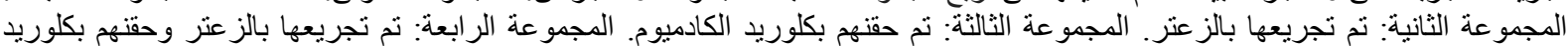

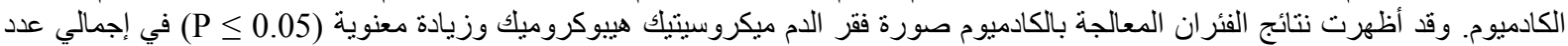

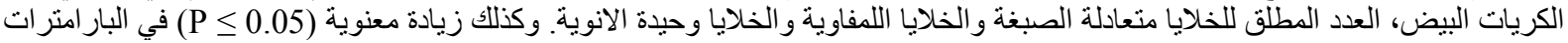

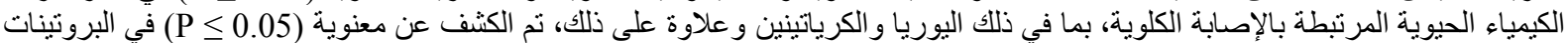

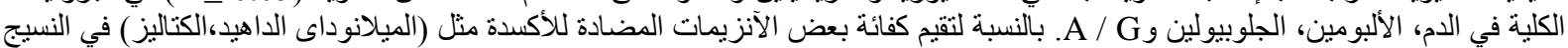

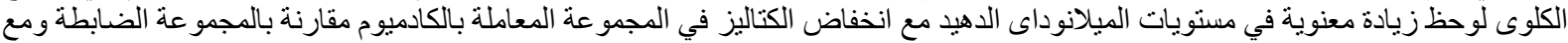

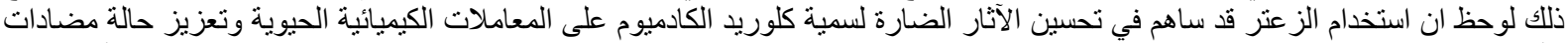

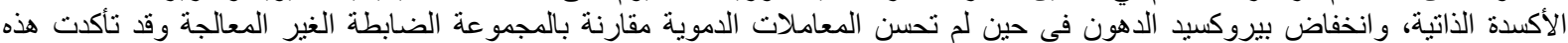

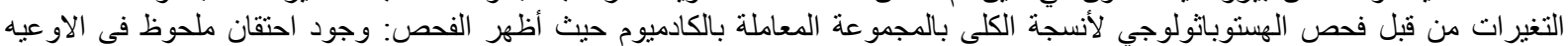

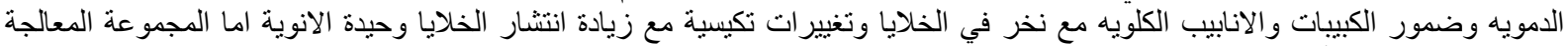

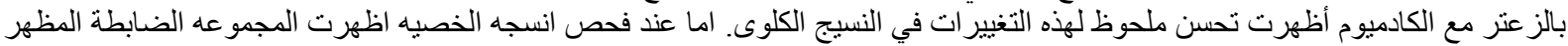

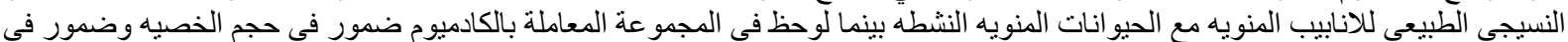

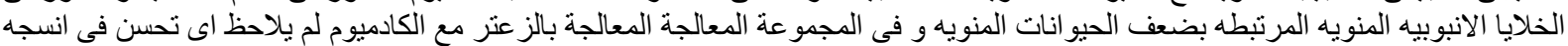

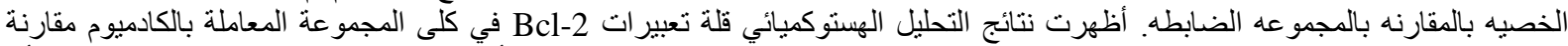

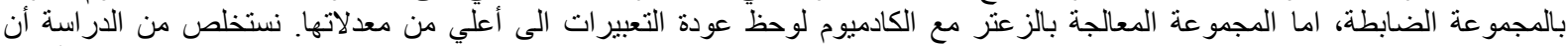

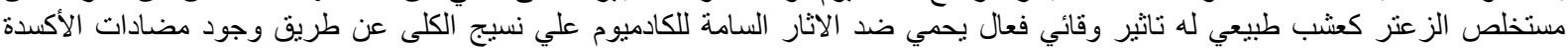

